\title{
SYNTHESIS, CHARACTERIZATION AND ANTIOXIDANT ACTIVITY OF SOME TRANSITION METAL COMPLEXES WITH TERPENOID DERIVATIVES
}

\author{
ALKA CHOUDHARY ${ }^{a}$, RENU SHARMA ${ }^{a}$, MEENA NAGAR ${ }^{a *}$, MOHAMMED MOHSIN ${ }^{b}$ AND \\ HAR SAHAY MEENA ${ }^{b}$
}

\author{
${ }^{a}$ Department of Chemistry, University of Rajasthan, Jaipur-302 004, India \\ ${ }^{b}$ Defence Institute of Bio-Energy Research, Pithoragarh-262 501,Uttarakhand, India
}

(Received: April 8, 2011 - Accepted: October 13, 2011)

\begin{abstract}
A series of transition metal complexes of $\mathrm{Fe}(\mathrm{III}), \mathrm{Co}(\mathrm{II})$ and $\mathrm{Cu}(\mathrm{II})$ containing the bidentate $\mathrm{N}, \mathrm{O}$ and N,S donor ligand, camphor semicarbazone (1,7,7-trimethylbicyclo [2,2,1] heptanesemicarbazone, TBHSC) and camphor thiosemicarbazone (1,7,7- trimethylbicyclo [2,2,1]heptanethiosemicarbazone, TBHTSC) have been synthesized and characterized by elemental analysis, molar conductance measurement and various spectral studies (IR, electronic and FAB Mass) and thermogravimetric analysis (TGA). All the metal complexes (1-8) are $\left[\mathrm{M}(\mathrm{LH}) \mathrm{Cl}_{2}\right]$ and $\left[\mathrm{M}(\mathrm{LH})_{2} \mathrm{Cl}_{2}\right]$ type, where $\mathrm{M}=\mathrm{Fe}(\mathrm{III}), \mathrm{Co}(\mathrm{II})$ and $\mathrm{Cu}(\mathrm{II})$; $\mathrm{LH}=$ TBHSC and TBHTSC. TBHSC and TBHTSC act as neutral bidentate ligands in all the complexes. FAB mass spectroscopic studies of the three representative complexes (1), (2), (4), (5) and (8) suggest their monomeric nature. The proposed geometries of the complexes were octahedral geometry for 1:2 complexes, square planar for $1: 1$ complexes and distorted octahedral for $\mathrm{Cu}$ (II) complexes (1:2). The free radical scavenging activity of newly synthesized ligands (TBHSC, TBHTSC) and their metal complexes have been determined at the concentration range of $50-1000 \mu \mathrm{g} / \mathrm{ml}$ by means of their interaction with the stable free radical 1,1-diphenyl-2-picrylhydrazyl (DPPH). All the compounds have shown encouraging antioxidant activities. The least IC $\mathrm{s}_{50}$ value $(111.0 \mu \mathrm{g} / \mathrm{ml})$ for compound (5) showed the potent scavenging property compared to other test compounds.
\end{abstract}

Keywords: molar conductance; thermogravimetric analysis; radical scavenging activity; DPPH.

\section{INTRODUCTION}

Thiosemicarbazones are well established as an important class of sulfur donor ligands particularly for transition metal ions..$^{1-6}$ During the last few decades there has been a growing interest in the pharmacological properties of semicarbazones, thiosemicarbazones and their metal complexes due to their ability to function as antiviral, antibacterial, antifungal, anticancer and antioxidant agents. ${ }^{7-13}$ The activity is usually increased by complexation therefore to understand the properties of both ligands and metal can lead to the synthesis of highly active compounds. ${ }^{14-20}$ The influence of certain metals on the biological activity of these compounds and their intrinsic chemical interest as multidentate ligands has prompted a considerable increase in the study of their coordination behavior. ${ }^{21-23}$ Previously, we have reported the structural and spectral studies of transition metal complexes of some acyclic monoterpenic constituents of essential oils. ${ }^{24,25}$ Our ongoing research work on transition metal complexes with semicarbazones and thiosemicarbazones involving such systems led us to describe the synthesis, characterization and antioxidant activity of some transition metal complexes with semicarbazone and thiosemicarbazone derived from camphor (1,7,7-trimethylbicyclo $[2,2,1]$ heptane-2-one). Camphor is a bicyclic monoterpenone and important constituent of several essential oils, e.g. sage oil..$^{26}$ The preparation and study of inorganic compounds containing biologically important ligands is made easier because metal ions used are active in many biological processes. ${ }^{27-29}$ The fact that transition metals are essential metallic elements and exhibit great biological activity when associated with certain metal electronic transfer reactions or the storage of ion $^{30-32}$ has created attention in the study of system.

Drugs with antioxidant mechanisms are being widely proposed as starting point for the development of new therapeutic interventions in several pathological disorders associated with oxidative damage, caused by reactive oxygen species (ROS), including hydrogen peroxide, superoxide anion and hydroxyl radical, under conditions of 'oxidative stress' ${ }^{33,34}$ This term refers to an imbalance between ROS production and detoxification, in favour of the former, and it is characterized by excessive production of ROS and reduction in the responsible for their metabolism antioxidant defences. ${ }^{35,36}$

Antioxidants are the compounds, which terminate the attack of reactive species like free radicals and prevent it from ageing and different disease associated with oxidative damages inside the body system. ${ }^{37}$ Antioxidant activity of a synthetic compound can be measured using the scavenging potential of that compound for the trapping of free radicals. These free radicals can oxidize biomolecules viz. nucleic acids, proteins, lipids, DNA, tissue damage and can initiate degenerative diseases, oxidative damage plays a significantly pathological role in human diseases such as cancer, emphysema, cirrhosis, atherosclerosis and arthritis etc. ${ }^{38,39}$ Almost all organisms are protected to some extent by free radical (peroxide, hydro-peroxide or lipid peroxyl) damage by enzymes such as super-oxide dismutase and catalase or compounds such as ascorbic acid, tocopherols, phenolic acids, polyphenols, flavonoids and glutathione. ${ }^{40}$ However, antioxidant supplements or dietary antioxidants may be sources of protection that the body needs to protect against the damaging effects of free radicals. ${ }^{41}$ Presently, synthetic antioxidants are widely used because they are effective and cheaper than natural antioxidants.

\section{EXPERIMENTAL SECTION}

\section{Material and Methods}

All the chemicals and reagents used were of AR grade. Solvents were dried by conventional methods and distilled prior to use. Ligands were prepared by method reported earlier. ${ }^{24,42}$ Metal contents were measured by complexometric titration $^{48}$. Sulfur was estimated gravimetrically as $\mathrm{BaSO}_{4}$ and chloride content was determined by Volhard's Methods. ${ }^{43}$

Elemental analyses were carried out on Thermoquest analyzer. The IR spectra were recorded with $\mathrm{KBr}$ pellets in the $4000-225 \mathrm{~cm}^{-1}$ range on Nicolet Megna 550 FT-IR spectrometer. The ${ }^{1} \mathrm{H}$ and ${ }^{13} \mathrm{C}\left\{{ }^{1} \mathrm{H}\right\}$ NMR spectra of ligands were collected in $\mathrm{CDCl}_{3}$ solution using TMS as internal standard on JEOL FX 300 FT-NMR spectrometer at 300.4 and $75.45 \mathrm{MHz}$ frequencies for ${ }^{1} \mathrm{H}$ and ${ }^{13} \mathrm{C}\left\{{ }^{1} \mathrm{H}\right\}$ NMR, respectively and electronic spectra were recorded on a Agilent UV/Visible spectrometer. Molar conductivities of $10^{-3} \mathrm{M}$ DMSO solutions were measured on a microprocessor based conductivity meter model 1601/E. Thermogravimetric analysis was performed by Perkin Elmer Thermal Analyzer with the heating rate $35-800 / 10^{\circ} \mathrm{C}$ under nitrogen atmosphere. Mass spectra were recorded on Shimadzu Mass Spectrophotometer. Antioxidant activity was measured on Spectro UV-Vis double beam PC scanning spectrophotometer (LABOMED. INC) Vortex (SPINIX)

Synthesis of Ligands

Synthesis of 1,7,7-trimethylbicyclo $[2,2,1]$ heptanethiosemicarbazone (TBHTSC)

The equimolar quantity of $( \pm)$ camphor $(3.04 \mathrm{~g}, 20 \mathrm{mmol})$ and thiosemicarbazide $(1.83 \mathrm{~g}, 20 \mathrm{mmol})$ was dissolved in ethanol $(50 \mathrm{~mL})$ and few drops of conc. $\mathrm{H}_{2} \mathrm{SO}_{4}$ were added. The reaction mixture was refluxed for 6 $\mathrm{h}$ and then kept in ice for overnight. The resulting white solid was filtered, recrystallized from water and ethanol mixture and dried over $\mathrm{P}_{2} \mathrm{O}_{5}$ Yield: $75 \%$ (3.3 g); M. Pt. $137-139^{\circ} \mathrm{C}$; IR $\left(\mathrm{cm}^{-1}\right): 3425 \mathrm{~s}, 3225 \mathrm{~s}$, br $v\left(\mathrm{NH}_{2}\right)^{2} ; 3195 \mathrm{~s}$, n $(\mathrm{NH})$; $1595 \mathrm{~s}, \mathrm{n}(\mathrm{C}=\mathrm{N}) ; 875 \mathrm{~m}, \mathrm{n}(\mathrm{C}=\mathrm{S}) ; 945, \mathrm{n}(\mathrm{N}-\mathrm{N}) ;{ }^{1} \mathrm{H}$ NMR $\left(\mathrm{CDCl}_{3}, \mathrm{~d} \mathrm{ppm}\right): 0.74$ 
(s, 3H, H-8); 0.94 (s, 3H, H-10); 0.98 (s, 3H, H-9); 1.18-1.26 (m, 1H, H-5 endo); 1.33-1.42 (m, 1H, H-6 endo); 1.70-1.79 (m, 1H, H-6 exo); 1.80-1.85 (m, 1H, H-5 exo); 1.87-1.92 (m, 1H, H-4); 2.02-2.05 (m, 1H, H-3 endo); $2.36-$ $2.44(1 \mathrm{H}, \mathrm{H}-3 \mathrm{exo}) ; 7.27,7.23\left(2 \mathrm{~s}, 2 \mathrm{H}, \mathrm{NH}_{2}\right) ; 9.45(\mathrm{~s}, 1 \mathrm{H}, \mathrm{NH}-\mathrm{C}=\mathrm{S}) ;{ }^{13} \mathrm{C}$ NMR ( $\mathrm{CDCl}_{3}$, d ppm): $11.0(\mathrm{C}-10) ; 18.5$ (C-8 or C-9); 19.4 (C-8 or C-9); 27.1 (C-5); 32.4 (C-3); 33.8 (C-6); 43.9 (C-4); 47.9 (C-7); $52.3(\mathrm{C}-1) ; 167.2$ (C=N); 177.4 $(\mathrm{C}=\mathrm{S})$. Anal. Found for $\mathrm{C}_{11} \mathrm{H}_{19} \mathrm{~N}_{3} \mathrm{~S}(225.35)$ : $\mathrm{C}, 58.57 ; \mathrm{H}, 8.43 ; \mathrm{N}, 18.63 ; \mathrm{S}$, 14.31. Calcd. C, 58.62; H, 8.49; N, 18.64; S, $14.22 \%$.

Synthesis of 1,7,7-trimethylbicyclo $[2,2,1]$ heptanesemicarbazone (TBHSC)

An aqueous solution $(50 \mathrm{~mL})$ of semicarbazide hydrochloride $(3.34 \mathrm{~g}, 30$ $\mathrm{mmol}$ ) and crystalline sodium acetate $(4.08 \mathrm{~g}, 30 \mathrm{mmol})$ was added dropwise with constant stirring to an ethanolic solution $(50 \mathrm{~mL})$ of camphor $(4.56 \mathrm{~g}, 30$ $\mathrm{mmol}$ ) and refluxed. After $7 \mathrm{~h}$ refluxing TBHSC precipitated as white solid on cooling. It was filtered and recrystallized from water-ethanol mixture and dried in vacuum. Yield: : $90 \%(5.7 \mathrm{~g})$; M. Pt. $238-239^{\circ} \mathrm{C}$; IR $\left(\mathrm{cm}^{-1}\right): 3455 \mathrm{~s}, 3260 \mathrm{~s}$, br $v\left(\mathrm{NH}_{2}\right) ; 3232 \mathrm{~s}, \mathrm{n}(\mathrm{NH}) ; 1698, \mathrm{n}(\mathrm{C}=\mathrm{O}) ; 1553 \mathrm{~s}, \mathrm{n}(\mathrm{C}=\mathrm{N}) ; 960, \mathrm{n}(\mathrm{N}-\mathrm{N}) ;{ }^{1} \mathrm{H}$ NMR ( $\mathrm{CDCl}_{3}$, d ppm): 0.74 (s, 3H, H-8); 0.94 (s, 3H, H-10); 0.98 (s, 3H, H-9); 1.181.26 (m, 1H, H-5 endo); 1.33-1.42 (m, 1H, H-6 endo); 1.70-1.79 (m, 1H, H-6 exo); $1.80-1.85$ (m, $1 \mathrm{H}, \mathrm{H}-5$ exo); 1.86-1.94 (m, $1 \mathrm{H}, \mathrm{H}-4) ; 2.02-2.05$ (m, $1 \mathrm{H}$, $\mathrm{H}-3$ endo); 2.37-2.44 (m, 1H, H-3 exo); 7.28, $7.22\left(2 \mathrm{~s}, 2 \mathrm{H}, \mathrm{NH}_{2}\right) ; 8.40(\mathrm{~s}, 1 \mathrm{H}$, $\mathrm{NH}-\mathrm{C}=\mathrm{O}) ;{ }^{13} \mathrm{C}$ NMR $\left(\mathrm{CDCl}_{3}\right.$, d ppm): $11.0(\mathrm{C}-10) ; 18.6(\mathrm{C}-8$ or C-9); 19.4 (C-8 or C-9); 27.2 (C-5); 32.5 and 33.5 (C-3 and C-6); 43.9 (C-4); 47.9 (C-7); $52.3(\mathrm{C}-1) ; 158.1(\mathrm{C}=\mathrm{N}) ; 163.5(\mathrm{C}=\mathrm{O})$. Anal. Found for $\mathrm{C}_{11} \mathrm{H}_{10} \mathrm{~N}_{3} \mathrm{O}(209.28)$ : C, 63.06; H, 9.07; N, 20.06. Calcd. C, 63.12; H, 9.15; N, 20.07\%.

Preparation of metal complexes in $(1: 1)$ and $(1: 2)$ molar ratio with camphor thiosemicarbazone and $(1: 2)$ with camphor semicarbazone

To an ethanolic solution $(\sim 20 \mathrm{ml})$ of $\mathrm{CoCl}_{2} .6 \mathrm{H}_{2} \mathrm{O}(2.39 \mathrm{~g}, 10 \mathrm{mmol})$, a hot ethanolic solution $(\sim 25 \mathrm{ml})$ of ligand (TBHTSC) $(2.28 \mathrm{~g}, 10 \mathrm{mmol})$ was added dropwise with constant stirring. After complete addition the reaction mixture was refluxed for $6 \mathrm{~h}$. and cooled to room temperature. The solvent was evaporated under vacuum and the residue dark blue precipitate was washed with anhydrous ethanol and diethyl ether and dried in vacuum to give dark blue coloured solid. Similar route have been employed for the preparation of $\mathrm{Cu}(\mathrm{II})$ complex.

To an ethanolic solution $(\sim 20 \mathrm{~mL})$ of $\mathrm{CoCl}_{2} \cdot 6 \mathrm{H}_{2} \mathrm{O}(1.19 \mathrm{~g}, 5 \mathrm{mmol})$, a hot ethanolic solution $(\sim 25 \mathrm{~mL})$ of ligand (TBHTSC) $(2.25 \mathrm{~g}, 10 \mathrm{mmol})$ was added dropwise with constant stirring. After complete addition the reaction mixture was refluxed for $c a .4 \mathrm{~h}$ and cooled to room temperature. The resulting dark blue precipitate was filtered, washed several times with anhydrous ethanol and dried under reduced pressure.

Similar route have been employed for the preparation of other complexes.

\section{ANTIOXIDANT ACTIVITY}

Antioxidant activity of the compounds was estimated by DPPH radical scavenging effect. The method for estimating free radical scavenging activity of the methanolic solutions of bioactive compounds were under taken as suggested by Hatano et al. (1988). ${ }^{44}$ The DPPH reagent evidently offers a convenient and accurate method for titrating the oxidizable groups of natural or synthetic antioxidants. ${ }^{45}$

The $\%$ scavenging activity was calculated (Table 6 ) by using the formula:

$\%$ Scavenging Activity $=[(\mathrm{A}-\mathrm{A}) / \mathrm{A}] \times 100$

Where, $\mathrm{A}_{\mathrm{c}}=$ Absorbance of the control sample

$\mathrm{A}=$ Absorbance of the test sample after $40 \mathrm{~min}$.

The scavenging activity was expressed as $\mathrm{IC}_{50}$ value (Table 7), which is defined as the concentration $(\mu \mathrm{g} / \mathrm{ml})$ of compound required for scavenging of DPPH radicals by $50 \% . \mathrm{IC}_{50}$ values were determined by linear regression analysis using at least five different concentrations in duplicate. ${ }^{46}$

\section{RESULTS AND DISCUSSION}

A systematic study of the reactions of metal chlorides with ligand TBHTSC in 1:1 and 1:2 and TBHSC in 1:2 molar ratio in molar ratio in EtOH have been carried out. The reactions can be represented by following equation

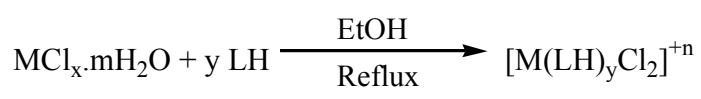

\{Where $\mathrm{M}=\mathrm{Fe}(\mathrm{III}), \mathrm{Co}(\mathrm{II}), \mathrm{Cu}(\mathrm{II}) ; \mathrm{x}=2$ for $\mathrm{Co}(\mathrm{II}), \mathrm{Cu}(\mathrm{II})$ and 3 for $\mathrm{Fe}(\mathrm{III})$; $\mathrm{m}=0$ for $\mathrm{Fe}(\mathrm{III}), 2$ for $\mathrm{Cu}(\mathrm{II})$ and 6 for $\mathrm{Co}(\mathrm{II}) ; \mathrm{y}=1$ or 2 for $\mathrm{LH}=$ TBHTSC, $\mathrm{y}$ $=2$ for $\mathrm{LH}=\mathrm{TBHSC} ; \mathrm{n}=0$ for $\mathrm{Co}(\mathrm{II}), \mathrm{Cu}(\mathrm{II})$ and 1 for $\mathrm{Fe}(\mathrm{III})$

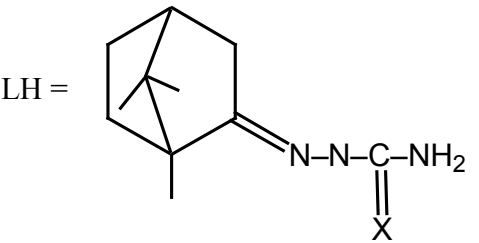

Where $\begin{aligned} \mathrm{X} & =\mathrm{O}(\text { TBHSC) } \\ \mathrm{X} & =\mathrm{S} \text { (TBHTSC) }\end{aligned}$

Several analytical techniques were used to characterize the complexes including microanalysis (CHN), spectral studies (IR, electronic and FAB mass), thermogravimetric analysis (TGA) and conductometric measurements. Analytical data for the newly synthesized complexes are given in Table 1. All the metal complexes are non-hygroscopic in nature, stable at room temperature, insoluble in water but soluble in DMSO, THF and $\mathrm{CH}_{2} \mathrm{Cl}_{2}$.

The molar conductivity shows that all the complexes are non-electrolytes with $1=17.8-23.7 \Omega^{-1} \mathrm{~cm}^{2} \mathrm{~mol}^{-1}$ in DMSO $\left(10^{-3} \mathrm{M}\right)$ solution at room temperature.

Infrared spectra

The main IR spectral bands of complexes and their assignments are presented in Table 2. In the spectrum of TBHSC amide $(\mathrm{C}=\mathrm{O})$ band observed at $1698 \mathrm{~cm}^{-1}$ is shifted to lower frequency due to coordination of amido oxygen to metal ion ${ }^{24}$. The ligand TBHTSC shows band at $875 \mathrm{~cm}^{-1}$ which shifted to the downward region in the complexes suggests the coordination of metal ion through the $\mathrm{C}=\mathrm{S}$ group ${ }^{24}$. The spectra of both ligands exhibit a band in the $1553-1580 \mathrm{~cm}^{-1}$ region due to $\mathrm{C}=\mathrm{N}$ mode of azomethine linkage. In the metal complexes this band shifted to lower frequency suggesting that the unsaturated nitrogen of azomethine linkage is coordinated to metal ${ }^{24,42}$. In ligands the highest frequency bands observed in 3425-3455 $\mathrm{cm}^{-1}$ and $3225-3260 \mathrm{~cm}^{-1}$ regions are assigned to asymmetric and symmetric stretching of terminal $\mathrm{NH}_{2}$ group vibration. The second highest band observed at 3195-3232 $\mathrm{cm}^{-1}$ region due to the imino group stretching vibration. In the complexes the above bands are not affected indicating non-participation of amino and imino nitrogen atoms in coordination.

In the IR spectra of all the metal complexes, the bands observed in the regions 420-480 and 320-382 $\mathrm{cm}^{-1}$ can be assigned to M-N and M-Cl stretching respectively ${ }^{4}$. The bonding of oxygen to the metal ions in the corresponding semicarbazone complexes is proved by the occurrence of the $v(\mathrm{M}-\mathrm{O})$ band at the $425-472 \mathrm{~cm}^{-1}$ region ${ }^{24}$. The bonding of sulfur to the metal ion in the corresponding thiosemicarbazone complexes is indicated by the occurrence of the $v(\mathrm{M}-\mathrm{S})$ band at the $322-392 \mathrm{~cm}^{-1}$ region ${ }^{4}$.

\section{Electronic Spectra}

The electronic spectrum of Fe(III) complexes shows $801 \mathrm{~nm}$ and $575 \mathrm{~nm}$ may be assigned to ${ }^{6} \mathrm{~A}_{1 \mathrm{~g}}{ }^{\circledR}{ }^{4} \mathrm{~T}_{1 \mathrm{~s}}$ and ${ }^{6} \mathrm{~A}{ }^{\circledR 4} \mathrm{~T}_{2 \mathrm{~g}}$ transitions, respectively, in an octahedral geometry around $\mathrm{Fe}(\mathrm{III}) .{ }^{47} \mathrm{The}$ electronic spectrum of the cobalt(II) complexes exhibit four bands at $907,682,608$ and $260 \mathrm{~nm}$, which are assigned to ${ }^{4} \mathrm{~T}_{1 \mathrm{~g}}{ }^{\circledR}{ }^{4} \mathrm{~T}_{2 \mathrm{~g}}(\mathrm{~F}),{ }^{4} \mathrm{~T}_{1 \mathrm{~g}}{ }^{\circledR}{ }^{4} \mathrm{~T}_{1 \mathrm{~g}}(\mathrm{P}),{ }^{4} \mathrm{~T}_{1 \mathrm{~g}}{ }^{\circledR}{ }^{4} \mathrm{~A}_{2 \mathrm{~g}}$ and charge transfer transitions of the $\mathrm{d}^{7}$ system. Therefore, octahedral geometry was proposed for cobalt(II) complex. $^{48-50}$

The $\mathrm{Cu}(\mathrm{II})$ complexes shows bands at 948, 621 and $408 \mathrm{~nm}$ which are assigned to ${ }^{2} \mathrm{~B}_{1 \mathrm{~g}}{ }^{\circledR}{ }^{2} \mathrm{~A}_{1 \mathrm{~g}}\left(v_{1}\right),{ }^{2} \mathrm{~B}_{1 \mathrm{~g}}{ }^{\circledR}{ }^{2} \mathrm{~B}_{2 \mathrm{~g}}\left(v_{2}\right)$ and ${ }^{2} \mathrm{Eg}\left(v_{3}\right)$ transitions. The positions of these bands and their assignments suggest distorted octahedral geometry. ${ }^{51}$ The absorption bands appearing in the UV domain are considered to the characteristics of the ligand. The assignment of $n-p^{*}$ and $\mathrm{p}-\mathrm{p}^{*}$ transition as being due to the $(\mathrm{C}=\mathrm{O})$ and $(\mathrm{C}=\mathrm{S})$ bond. The electronic spectrum of [Co(TBHTSC)Cl $]_{2}$ exhibits three bands at 1098, 980 and $675 \mathrm{~nm}$. The first two bands are assigned to ${ }^{2} \mathrm{~B}_{2 \mathrm{~g}}{ }^{2} \mathrm{E}_{\mathrm{g}}$ and ${ }^{2} \mathrm{~B}_{2}{ }^{2} \mathrm{~A}_{\mathrm{g}}$ transitions, respectively, in a square planar environment of ${ }^{\mathrm{g}} \mathrm{Co}(\mathrm{II})^{51}$. The spectrum of [Cu(TBHTSC) $\mathrm{Cl}_{2}$ ] shows a band at $489 \mathrm{~nm}$ indicates square planar geometry for $\mathrm{Cu}(\mathrm{II})$ complex ${ }^{52,53}$. (Table 3 ). 
Table 1. Physical and analytical data for complexe.

\begin{tabular}{|c|c|c|c|c|c|c|c|c|c|c|}
\hline \multirow{2}{*}{$\begin{array}{l}\text { Compound } \\
\text { (Empirical formula) }\end{array}$} & \multirow[b]{2}{*}{ Colour } & \multirow[b]{2}{*}{ M. Pt. } & \multirow[b]{2}{*}{$\begin{array}{l}\text { Yield } \\
(\%)\end{array}$} & \multirow[b]{2}{*}{$\begin{array}{c}\text { Molar } \\
\text { conductance } \\
\left(\mathrm{Col}^{-1} \mathrm{~cm}^{2}\right)\end{array}$} & \multicolumn{6}{|c|}{ Found (Calcd.) \% } \\
\hline & & & & & $\mathbf{C}$ & $\mathbf{H}$ & $\mathbf{N}$ & $\mathbf{S}$ & M & Cl \\
\hline $\begin{array}{l}{\left[\mathrm{Cu}(\mathrm{TBHTSC}) \mathrm{Cl}_{2}\right](2)} \\
{\left[\mathrm{Cu}\left(\mathrm{C}_{11} \mathrm{H}_{19} \mathrm{~N}_{3} \mathrm{~S}\right) \mathrm{Cl}_{2}\right]}\end{array}$ & Green & 262 & 78 & 18.4 & $\begin{array}{c}36.50 \\
(36.72)\end{array}$ & $\begin{array}{c}5.01 \\
(5.32)\end{array}$ & $\begin{array}{c}11.98 \\
(11.67)\end{array}$ & $\begin{array}{c}7.99 \\
(8.91)\end{array}$ & $\begin{array}{c}16.75 \\
(17.66)\end{array}$ & $\begin{array}{c}18.76 \\
(19.70)\end{array}$ \\
\hline $\begin{array}{l}{\left[\mathrm{Fe}(\mathrm{TBHTSC})_{2} \mathrm{Cl}_{2}\right] \mathrm{Cl}(\mathbf{3})} \\
{\left[\mathrm{Fe}\left(\mathrm{C}_{11} \mathrm{H}_{19} \mathrm{~N}_{3} \mathrm{~S}\right)_{2} \mathrm{Cl}_{2}\right] \mathrm{Cl}}\end{array}$ & Brown & 81 & 89 & 19.2 & $\begin{array}{l}43.18 \\
(43.11)\end{array}$ & $\begin{array}{c}7.03 \\
(6.24)\end{array}$ & $\begin{array}{l}13.60 \\
(13.71)\end{array}$ & $\begin{array}{l}10.04 \\
(10.46)\end{array}$ & $\begin{array}{l}8.93 \\
(9.11)\end{array}$ & $\begin{array}{r}17.63 \\
(17.35)\end{array}$ \\
\hline $\begin{array}{l}{\left[\mathrm{Co}(\mathrm{TBHTSC})_{2} \mathrm{Cl}_{2}\right](4)} \\
{\left[\mathrm{Co}\left(\mathrm{C}_{11} \mathrm{H}_{19} \mathrm{~N}_{3} \mathrm{~S}\right)_{2} \mathrm{Cl}_{2}\right]}\end{array}$ & $\begin{array}{l}\text { Dark } \\
\text { blue }\end{array}$ & 194 & 85 & 23.7 & $\begin{array}{l}45.15 \\
(45.51)\end{array}$ & $\begin{array}{l}6.93 \\
(6.59)\end{array}$ & $\begin{array}{l}14.11 \\
(14.47)\end{array}$ & $\begin{array}{l}11.19 \\
(11.04)\end{array}$ & $\begin{array}{l}10.02 \\
(10.15)\end{array}$ & $\begin{array}{l}12.29 \\
(12.21)\end{array}$ \\
\hline $\begin{array}{l}{\left[\mathrm{Fe}(\mathrm{TBHSC})_{2} \mathrm{Cl}_{2}\right] \mathrm{Cl} \text { (6) }} \\
{\left[\mathrm{Fe}\left(\mathrm{C}_{11} \mathrm{H}_{19} \mathrm{~N}_{3} \mathrm{O}\right)_{2} \mathrm{Cl}_{2}\right] \mathrm{Cl}}\end{array}$ & Brown & 199 & 85 & 17.8 & $\begin{array}{l}45.11 \\
(45.49) \\
\end{array}$ & $\begin{array}{r}5.95 \\
(6.59)\end{array}$ & $\begin{array}{l}14.49 \\
(14.46) \\
\end{array}$ & - & $\begin{array}{l}9.10 \\
(9.61)\end{array}$ & $\begin{array}{l}17.99 \\
(18.31)\end{array}$ \\
\hline $\begin{array}{l}{\left[\mathrm{Co}(\mathrm{TBHSC})_{2} \mathrm{Cl}_{2}\right](7)} \\
{\left[\mathrm{Co}\left(\mathrm{C}_{11} \mathrm{H}_{19} \mathrm{~N}_{3} \mathrm{O}\right)_{2} \mathrm{Cl}_{2}\right]}\end{array}$ & Pink & 231 & 74 & 22.9 & $\begin{array}{l}48.53 \\
(48.18)\end{array}$ & $\begin{array}{c}6.43 \\
(6.98)\end{array}$ & $\begin{array}{l}15.15 \\
(15.32)\end{array}$ & - & $\begin{array}{c}9.83 \\
(10.74)\end{array}$ & $\begin{array}{r}14.07 \\
(12.92)\end{array}$ \\
\hline $\begin{array}{l}{\left[\mathrm{Cu}(\mathrm{TBHSC})_{2} \mathrm{Cl}_{2}\right](\mathbf{8})} \\
{\left[\mathrm{Cu}\left(\mathrm{C}_{11} \mathrm{H}_{19} \mathrm{~N}_{3} \mathrm{O}\right)_{2} \mathrm{Cl}_{2}\right]}\end{array}$ & $\begin{array}{l}\text { Parrot } \\
\text { green }\end{array}$ & 194 & 90 & 18.9 & $\begin{array}{l}47.38 \\
(47.78)\end{array}$ & $\begin{array}{r}6.81 \\
(6.92)\end{array}$ & $\begin{array}{l}15.40 \\
(15.19)\end{array}$ & - & $\begin{array}{l}11.30 \\
(11.49)\end{array}$ & $\begin{array}{l}13.10 \\
(12.82)\end{array}$ \\
\hline
\end{tabular}

Table 2. Main IR spectral vibrations for complexes.

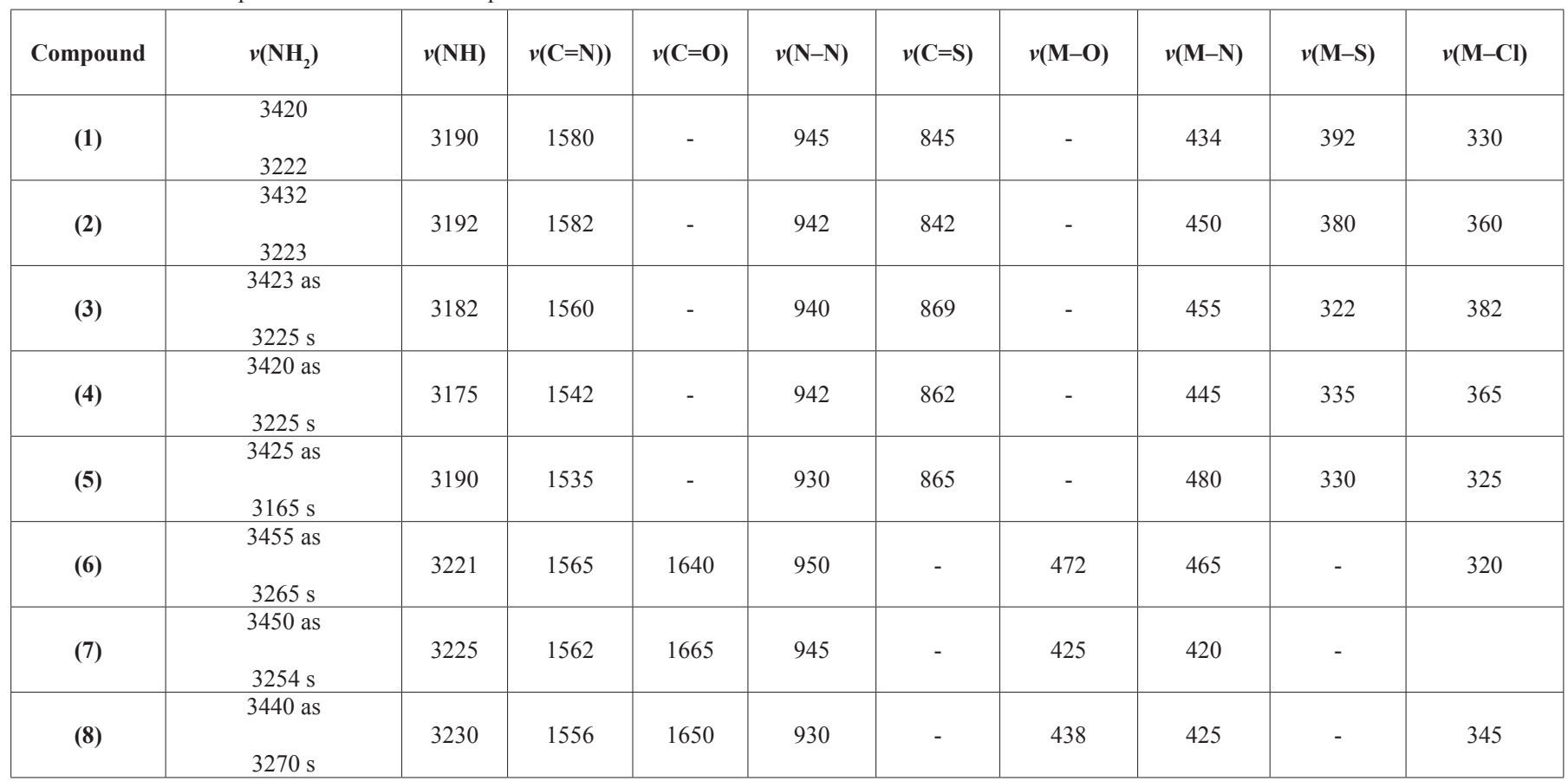


Table 3. Electronic absorption bands in complexes

\begin{tabular}{|c|c|}
\hline Compound & Electronic spectral bands \\
\hline $\mathbf{( 1 )}$ & $1098 ; 980 ; 675$ \\
\hline $\mathbf{( 2 )}$ & 489 \\
\hline $\mathbf{( 3 )}$ & $825 ; 575$ \\
\hline $\mathbf{( 4 )}$ & $881 ; 660 ; 620 ; 252$ \\
\hline $\mathbf{( 5 )}$ & $930 ; 625 ; 441$ \\
\hline $\mathbf{( 6 )}$ & $840 ; 562$ \\
\hline $\mathbf{( 7 )}$ & $892 ; 685 ; 608 ; 254$ \\
\hline $\mathbf{( 8 )}$ & $942 ; 612 ; 415$ \\
\hline
\end{tabular}

Thermal Studies

The thermogram for complexes $\left[\mathrm{Co}(\mathrm{TBHTSC}) \mathrm{Cl}_{2}\right](\mathbf{1})$ and $[\mathrm{Cu}(\mathrm{TBHTSC})$ $\left.\mathrm{Cl}_{2}\right]$ (2) revealed three step decomposition behavior (Fig. 2a,b). These TG steps are connected with exothermic events caused due to the pyrolysis of organic byproducts. The thermogram, also exhibits completion of the decomposition at $900^{\circ} \mathrm{C}$. The residual for complex (1) was $29.70 \%$ (obs.), corresponding to the formation of $\mathrm{Co}_{2} \mathrm{~S}_{3}$ (calcd. 30.13\%). The residual for complex (2) was $26.48 \%$ (obs.), corresponding to the formation of $\mathrm{CuS}$ (calcd. 26.57\%).

The thermogram for complex $\left[\mathrm{Cu}\left(\mathrm{C}_{11} \mathrm{H}_{19} \mathrm{~N}_{3} \mathrm{~S}\right)_{2} \mathrm{Cl}_{2}\right]$ (5) (Fig. 2c) revealed a three step decomposition behavior. These $\mathrm{TG}$ steps are connected with exothermic events caused due to the pyrolysis of organic byproducts. The thermogram, also exhibits completion of the decomposition at $800^{\circ} \mathrm{C}$. The residual was $14.65 \%$, corresponding to the formation of $\mathrm{Cu}_{2} \mathrm{~S}$ being the final product (Calcd. $13.59 \%$,).

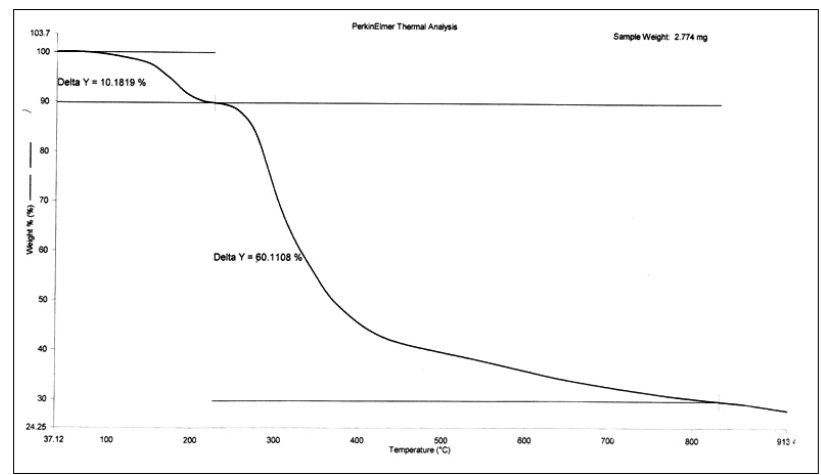

(a)

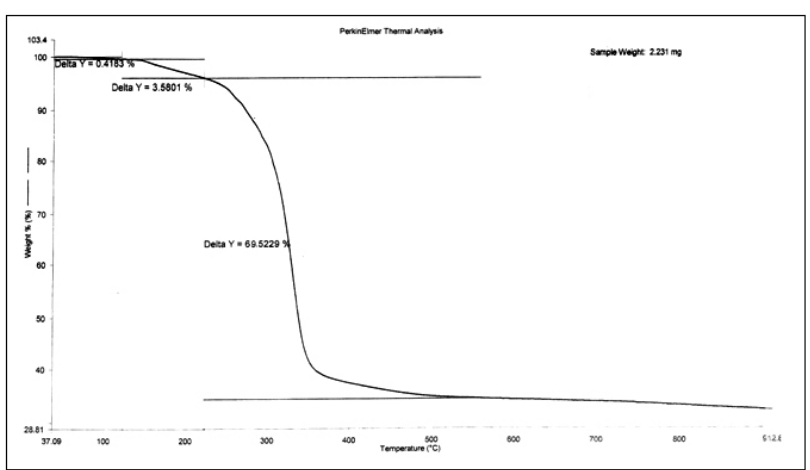

(b)

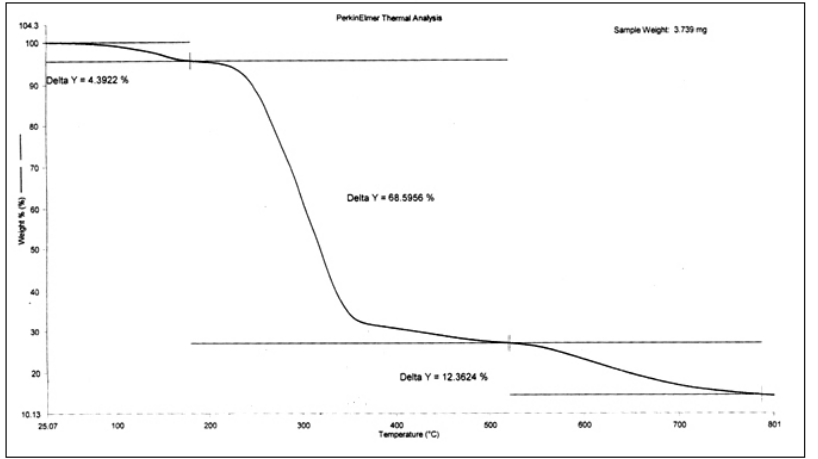

(c)

Fig. 2: TGA curve of $\left\{\right.$ weight $(\%)$ vs temperature $\left.\left({ }^{\circ} \mathrm{C}\right)\right\}$ (a) $[\mathrm{Co}$ (TBHTSC) $\left.\mathrm{Cl}_{2}\right]$

(b) $\left[\mathrm{Cu}\right.$ (TBHTSC) $\left.\mathrm{Cl}_{2}\right]$ and (c) $\left[\mathrm{Cu}(\mathrm{TBHTSC})_{2} \mathrm{Cl}_{2}\right]$

\section{Mass spectra}

The FAB mass spectral studies of three of the representative compounds, $\left[\mathrm{Co}\left(\mathrm{C}_{11} \mathrm{H}_{19} \mathrm{~N}_{3} \mathrm{~S}\right) \mathrm{Cl}_{2}\right]$ (1), $\left[\mathrm{Cu}\left(\mathrm{C}_{11} \mathrm{H}_{19} \mathrm{~N}_{3} \mathrm{~S}\right) \mathrm{Cl}_{2}\right]$ (2), [ $\left.\mathrm{Co}\left(\mathrm{C}_{11} \mathrm{H}_{19} \mathrm{~N}_{3} \mathrm{~S}\right)_{2} \mathrm{Cl}_{2}\right]$ (4), $\left[\mathrm{Cu}\left(\mathrm{C}_{11} \mathrm{H}_{19} \mathrm{~N}_{3} \mathrm{~S}\right)_{2} \mathrm{Cl}_{2}\right](5)$ and $\left[\mathrm{Cu}\left(\mathrm{C}_{11} \mathrm{H}_{19} \mathrm{~N}_{3} \mathrm{O}\right)_{2} \mathrm{Cl}_{2}\right](\mathbf{8})$ (Table 4) indicate their monomeric nature. The molecular ion peaks of (2) and (5) appears at $\mathrm{m} / \mathrm{z}$ 359.58 and 585.0, thus confirming the formation of a metal complexes in 1:1 and 1:2 ratios. (Table 4 and Fig. 3a-e).

Table 4. Fragmented molecular ions $v s \mathrm{~m} / \mathrm{z}$ values of $\left[\mathrm{Co}\left(\mathrm{C}_{11} \mathrm{H}_{19} \mathrm{~N}_{3} \mathrm{~S}\right) \mathrm{Cl}_{2}\right]$ (1), $\left[\mathrm{Cu}\left(\mathrm{C}_{11} \mathrm{H}_{19} \mathrm{~N}_{3} \mathrm{~S}\right) \mathrm{Cl}_{2}\right](2)\left[\mathrm{Co}\left(\mathrm{C}_{11} \mathrm{H}_{19} \mathrm{~N}_{3} \mathrm{~S}\right)_{2} \mathrm{Cl}_{2}\right](4),\left[\mathrm{Cu}\left(\mathrm{C}_{11} \mathrm{H}_{19} \mathrm{~N}_{3} \mathrm{~S}\right)_{2} \mathrm{Cl}_{2}\right]$ (5) and $\left[\mathrm{Cu}\left(\mathrm{C}_{11} \mathrm{H}_{19} \mathrm{~N}_{3} \mathrm{O}\right)_{2} \mathrm{Cl}_{2}\right](8)$.

\begin{tabular}{|c|c|c|}
\hline Compound & Fragmented ions & $\mathrm{m} / \mathrm{z}$ value \\
\hline \multirow[t]{10}{*}[\mathrm{Co}(\mathrm{C}_{11}\mathrm{H}_{19}\mathrm{N}_{3}\mathrm{S})\mathrm{Cl}_{2}]{$(1)$} & {$\left[\mathrm{Co}\left(\mathrm{C}_{11} \mathrm{H}_{19} \mathrm{~N}_{3} \mathrm{~S}\right) \mathrm{Cl}_{2}\right]$} & 355.19 \\
\hline & {$\left[\mathrm{Co}\left(\mathrm{C}_{10} \mathrm{H}_{17} \mathrm{~N}_{3} \mathrm{~S}\right) \mathrm{Cl}_{2}\right]^{+}$} & 341.16 \\
\hline & {$\left[\mathrm{Co}\left(\mathrm{C}_{8} \mathrm{H}_{17} \mathrm{~N}_{2} \mathrm{~S}\right) \mathrm{Cl}_{2}\right]^{+}$} & 303.13 \\
\hline & {$\left[\mathrm{Co}\left(\mathrm{C}_{6} \mathrm{H}_{17} \mathrm{~N}_{2} \mathrm{~S}\right) \mathrm{Cl}_{2}\right]^{+}$} & 279.10 \\
\hline & {$\left[\mathrm{Co}\left(\mathrm{C}_{4} \mathrm{H}_{17} \mathrm{~N}_{2} \mathrm{~S}\right) \mathrm{Cl}_{2}\right]^{+}$} & 255.07 \\
\hline & {$\left[\mathrm{Co}\left(\mathrm{C}_{4} \mathrm{H}_{16} \mathrm{~N}_{2} \mathrm{~S}\right) \mathrm{Cl}_{2}\right]^{+}$} & 254.06 \\
\hline & {$\left[\mathrm{Co}\left(\mathrm{C}_{3} \mathrm{H}_{14} \mathrm{NS}\right) \mathrm{Cl}_{2}\right]^{+}$} & 228.04 \\
\hline & {$\left[\mathrm{Co}\left(\mathrm{C}_{3} \mathrm{H}_{11} \mathrm{~S}\right) \mathrm{Cl}_{2}\right]^{+}$} & 209.00 \\
\hline & {$\left[\mathrm{Co}\left(\mathrm{CH}_{9} \mathrm{~S}\right) \mathrm{Cl}_{2}\right]^{+}$} & 181.95 \\
\hline & {$\left[\mathrm{Co}\left(\mathrm{H}_{7} \mathrm{~S}\right) \mathrm{Cl}_{2}\right]^{+}$} & 167.93 \\
\hline \multirow{13}{*}[\mathrm{Cu}(\mathrm{C}_{11}\mathrm{H}_{19}\mathrm{N}_{3}\mathrm{S})\mathrm{Cl}_{2}]{$(2)$} & {$\left[\mathrm{Cu}\left(\mathrm{C}_{11} \mathrm{H}_{19} \mathrm{~N}_{3} \mathrm{~S}\right) \mathrm{Cl}_{2}\right]$} & 359.80 \\
\hline & {$\left[\mathrm{Cu}\left(\mathrm{C}_{11} \mathrm{H}_{18} \mathrm{~N}_{3} \mathrm{~S}\right) \mathrm{Cl}_{2}\right]^{+}$} & 358.72 \\
\hline & {$\left[\mathrm{Cu}\left(\mathrm{C}_{6} \mathrm{H}_{18} \mathrm{~N}_{3} \mathrm{~S}\right) \mathrm{Cl}_{2}\right]^{+}$} & 298.67 \\
\hline & {$\left[\mathrm{Cu}\left(\mathrm{C}_{5} \mathrm{H}_{12} \mathrm{~N}_{3} \mathrm{~S}\right) \mathrm{Cl}_{2}\right]^{+}$} & 280.62 \\
\hline & {$\left[\mathrm{Cu}\left(\mathrm{C}_{5} \mathrm{H}_{11} \mathrm{~N}_{3} \mathrm{~S}\right) \mathrm{Cl}_{2}\right]^{+}$} & 279.61 \\
\hline & {$\left[\mathrm{Cu}\left(\mathrm{C}_{5} \mathrm{H}_{10} \mathrm{~N}_{3} \mathrm{~S}\right) \mathrm{Cl}_{2}\right]^{+}$} & 278.61 \\
\hline & {$\left[\mathrm{Cu}\left(\mathrm{C}_{3} \mathrm{H}_{10} \mathrm{~N}_{3} \mathrm{~S}\right) \mathrm{Cl}_{2}\right]^{+}$} & 254.59 \\
\hline & {$\left[\mathrm{Cu}\left(\mathrm{C}_{3} \mathrm{H}_{8} \mathrm{~N}_{3} \mathrm{~S}\right) \mathrm{Cl}_{2}\right]^{+}$} & 252.58 \\
\hline & {$\left[\mathrm{Cu}\left(\mathrm{C}_{3} \mathrm{H}_{8} \mathrm{~N}_{2} \mathrm{~S}\right) \mathrm{Cl}_{2}\right]^{+}$} & 238.58 \\
\hline & {$\left[\mathrm{Cu}\left(\mathrm{C}_{2} \mathrm{H}_{8} \mathrm{~N}_{2} \mathrm{~S}\right) \mathrm{Cl}_{2}\right]^{+}$} & 226.58 \\
\hline & {$\left[\mathrm{Cu}\left(\mathrm{C}_{2} \mathrm{H}_{6} \mathrm{NS}\right) \mathrm{Cl}_{2}\right]^{+}$} & 210.56 \\
\hline & {$\left[\mathrm{Cu}\left(\mathrm{CH}_{2} \mathrm{H}_{3} \mathrm{~S}\right) \mathrm{Cl}_{2}\right]^{+}$} & 193.54 \\
\hline & {$\left[\mathrm{Cu}\left(\mathrm{CH}_{3} \mathrm{~S}\right) \mathrm{Cl}_{2}\right]^{+}$} & 181.53 \\
\hline \multirow[t]{6}{*}[\mathrm{Co}(\mathrm{C}_{11}\mathrm{H}_{19}\mathrm{N}_{3}\mathrm{S})_{2}\mathrm{Cl}_{2}]{$(4)$} & {$\left[\mathrm{Co}\left(\mathrm{C}_{11} \mathrm{H}_{19} \mathrm{~N}_{3} \mathrm{~S}\right)_{2} \mathrm{Cl}_{2}\right]$} & 580 \\
\hline & $\begin{array}{l}{\left[\mathrm{Co}\left(\mathrm{C}_{11} \mathrm{H}_{19} \mathrm{~N}_{3} \mathrm{~S}\right)\left(\mathrm{C}_{11} \mathrm{H}_{19} \mathrm{~N}_{3} \mathrm{~S}\right)\right.} \\
\mathrm{Cl}^{+}\end{array}$ & 545 \\
\hline & $\begin{array}{l}{\left[\mathrm{Co}\left(\mathrm{C}_{11} \mathrm{H}_{19} \mathrm{~N}_{3} \mathrm{~S}\right)\left(\mathrm{C}_{11} \mathrm{H}_{18} \mathrm{~N}_{3} \mathrm{~S}\right)\right.} \\
\mathrm{Cl}^{+}\end{array}$ & 544 \\
\hline & {$\left[\mathrm{Co}\left(\mathrm{C}_{11} \mathrm{H}_{19} \mathrm{~N}_{3} \mathrm{~S}\right)\left(\mathrm{C}_{11} \mathrm{H}_{18} \mathrm{~N}_{3} \mathrm{~S}\right)\right]^{+}$} & 509 \\
\hline & {$\left[\mathrm{Co}\left(\mathrm{C}_{11} \mathrm{H}_{17} \mathrm{~N}_{3}\right)\left(\mathrm{C}_{10} \mathrm{H}_{17} \mathrm{~N}_{2}\right)\right]^{+}$} & 415 \\
\hline & {$\left[\mathrm{Co}\left(\mathrm{C}_{10} \mathrm{H}_{16} \mathrm{~N}\right)\left(\mathrm{C}_{10} \mathrm{H}_{16} \mathrm{~N}\right)\right]^{+}$} & 359 \\
\hline
\end{tabular}




\begin{tabular}{|c|c|c|}
\hline & {$\left[\mathrm{Co}\left(\mathrm{C}_{10} \mathrm{H}_{16} \mathrm{~N}\right)(\mathrm{N})\right]^{+}$} & 223 \\
\hline & {$\left[\mathrm{Co}\left(\mathrm{C}_{10} \mathrm{H}_{16} \mathrm{~N}\right)\right]^{+}$} & 209 \\
\hline & {$\left[\left(\mathrm{C}_{10} \mathrm{H}_{16} \mathrm{~N}\right)\right]^{+}$} & 150 \\
\hline$\left[\mathrm{Cu}\left(\mathrm{C}_{11} \mathrm{H}_{19} \mathrm{~N}_{3} \mathrm{~S}\right)_{2} \mathrm{Cl}_{2}\right]$ (5) & {$\left[\mathrm{Cu}\left(\mathrm{C}_{11} \mathrm{H}_{19} \mathrm{~N}_{3} \mathrm{~S}\right)_{2} \mathrm{Cl}_{2}\right]$} & 585 \\
\hline & {$\left[\mathrm{Cu}\left(\mathrm{C}_{11} \mathrm{H}_{19} \mathrm{~N}_{3} \mathrm{~S}\right)_{2} \mathrm{Cl}\right]^{+}$} & 550 \\
\hline & {$\left[\mathrm{Cu}\left(\mathrm{C}_{11} \mathrm{H}_{19} \mathrm{~N}_{3} \mathrm{~S}\right)_{2}\right]^{+}$} & 514 \\
\hline & {$\left[\mathrm{Cu}\left(\mathrm{C}_{11} \mathrm{H}_{10} \mathrm{~N}_{3} \mathrm{~S}\right)\left(\mathrm{C}_{11} \mathrm{H}_{18} \mathrm{~N}_{3} \mathrm{~S}\right)\right]^{+}$} & 513 \\
\hline & $\begin{array}{l}{\left[\mathrm{Cu}\left(\mathrm{C}_{11} \mathrm{H}_{16} \mathrm{~N}_{3}\right)\left(\mathrm{C}_{10} \mathrm{H}_{16} \mathrm{~N}_{2}\right)\right]^{+}} \\
{\left[\mathrm{Cu}\left(\mathrm{C} \mathrm{C}^{+} \mathrm{H}\right)\left(\mathrm{C}^{\mathrm{H}} \mathrm{H}\right)\right]^{+}}\end{array}$ & $\begin{array}{l}418 \\
404\end{array}$ \\
\hline & {$\left[\mathrm{Cu}\left(\mathrm{C}_{10} \mathrm{H}_{16} \mathrm{~N}\right)\left(\mathrm{C}_{10} \mathrm{H}_{10} \mathrm{~N}\right)\right]^{+}$} & 364 \\
\hline & {$\left[\mathrm{Cu}\left(\mathrm{C}_{10} \mathrm{H}_{16} \mathrm{~N}\right)(\mathrm{N})\right]^{+}$} & 228 \\
\hline & {$\left[\mathrm{Cu}\left(\mathrm{C}_{10} \mathrm{H}_{16} \mathrm{~N}\right)\right]^{+}$} & 214 \\
\hline & {$\left[\left(\mathrm{C}_{10} \mathrm{H}_{16}^{10} \mathrm{~N}\right)\right]^{+}$} & 150 \\
\hline$\left[\mathrm{Cu}\left(\mathrm{C}_{11} \mathrm{H}_{19} \mathrm{~N}_{3} \mathrm{O}\right)_{2} \mathrm{Cl}_{2}\right] \mathbf{( 8 )}$ & {$\left[\mathrm{Cu}\left(\mathrm{C}_{11} \mathrm{H}_{19} \mathrm{~N}_{3} \mathrm{O}\right)_{2} \mathrm{Cl}_{2}\right]$} & 553 \\
\hline & {$\left[\mathrm{Cu}\left(\mathrm{C}_{11} \mathrm{H}_{19} \mathrm{~N}_{3} \mathrm{O}\right)\left(\mathrm{C}_{10} \mathrm{H}_{16} \mathrm{~N}\right) \mathrm{Cl}_{2}\right]^{+}$} & 494 \\
\hline & {$\left[\mathrm{Cu}\left(\mathrm{C}_{11} \mathrm{H}_{17} \mathrm{~N}_{2} \mathrm{O}\right)\left(\mathrm{C}_{10} \mathrm{H}_{16} \mathrm{~N}\right) \mathrm{Cl}_{2}\right]^{+}$} & 478 \\
\hline & {$\left[\mathrm{Cu}\left(\mathrm{C}_{11} \mathrm{H}_{17} \mathrm{~N}_{2} \mathrm{O}\right)\left(\mathrm{C}_{10} \mathrm{H}_{16} \mathrm{~N}\right) \mathrm{Cl}\right]^{+}$} & 443 \\
\hline & {$\left[\mathrm{Cu}\left(\mathrm{C}_{11} \mathrm{H}_{16} \mathrm{~N}_{2} \mathrm{O}\right)\left(\mathrm{C}_{10} \mathrm{H}_{16} \mathrm{~N}\right) \mathrm{Cl}\right]^{+}$} & 442 \\
\hline & {$\left[\mathrm{Cu}\left(\mathrm{C}_{10} \mathrm{H}_{16} \mathrm{~N}_{2}\right)\left(\mathrm{C}_{10} \mathrm{H}_{16} \mathrm{~N}\right) \mathrm{Cl}\right]^{+}$} & 414 \\
\hline & {$\left[\mathrm{Cu}\left(\mathrm{C}_{10} \mathrm{H}_{10} \mathrm{~N}\right)\left(\mathrm{C}_{10} \mathrm{H}_{16} \mathrm{~N}\right)\right]^{+}$} & 364 \\
\hline & {$\left[\mathrm{Cu}\left(\mathrm{C}_{10} \mathrm{H}_{10} \mathrm{~N}\right)(\mathrm{N})\right]^{+}$} & 228 \\
\hline & {$\left[\mathrm{Cu}\left(\mathrm{C}_{10} \mathrm{H}_{16} \mathrm{~N}\right)\right]^{+}$} & 214 \\
\hline & {$\left[\left(\mathrm{C}_{10} \mathrm{H}_{16} \mathrm{~N}\right)\right]^{+}$} & 150 \\
\hline
\end{tabular}
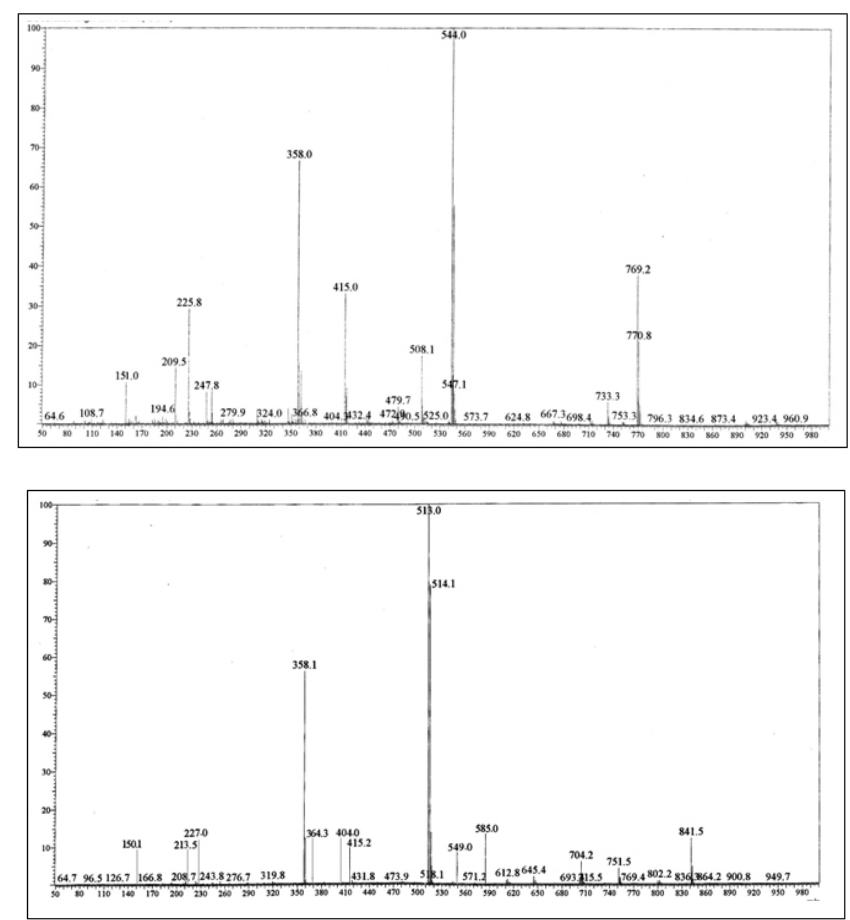

Fig.3a-e: Splitting patterns of FAB mass of \{intensity vs $\mathrm{m} / \mathrm{z}$ \} (a) $\left[\mathrm{Co}(\mathrm{TBHTSC}) \mathrm{Cl}_{2}\right], \quad$ (b) $\left[\mathrm{Cu}(\mathrm{TBHTSC}) \mathrm{Cl}_{2}\right],(\mathrm{c})\left[\mathrm{Co}(\mathrm{TBHTSC})_{2} \mathrm{Cl}_{2}\right]$, $\left[\mathrm{Cu}(\mathrm{TBHTSC})_{2} \mathrm{Cl}_{2}\right]$, and (e) $\left[\mathrm{Cu}(\mathrm{TBHSC})_{2} \mathrm{Cl}_{2}\right]$

On the basis of above analysis, the following structural formula (Fig. 1)

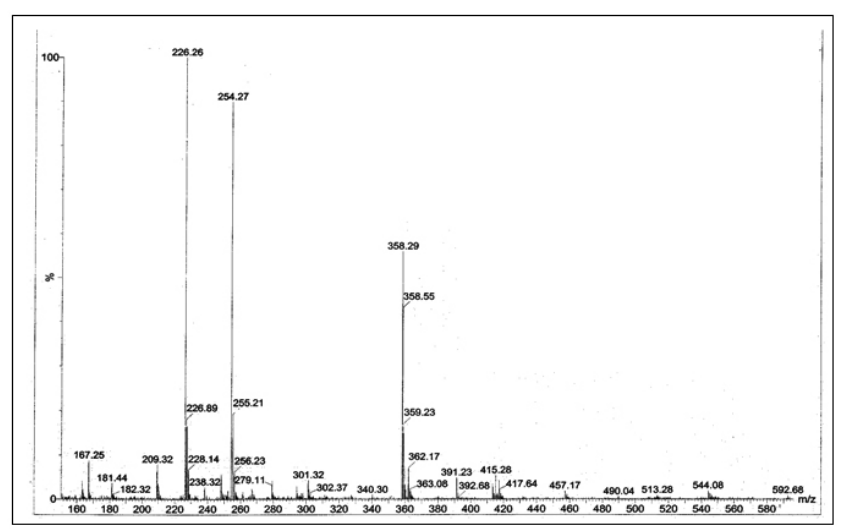
may be suggested for the complexes.

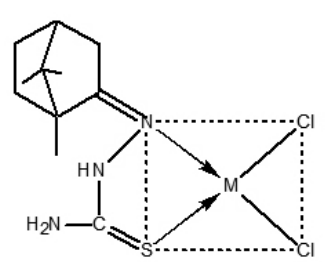

[Where $\mathrm{M}=\mathrm{Co}(\mathrm{II}), \mathrm{Cu}(\mathrm{II})$ ]

(a)

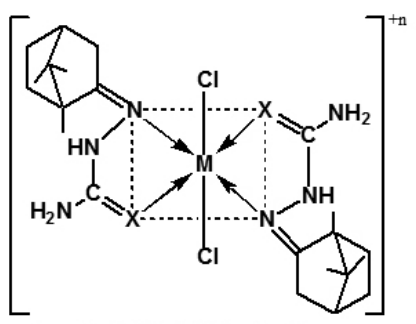

where $\mathrm{M}=\mathrm{Fe}$ (III), $\mathrm{Co}$ (II) and $\mathrm{Cu}$ (II) $\mathrm{n}=0$ for $\mathrm{Co}(\mathrm{II}), \mathrm{Cu}(\mathrm{II}) ; \mathrm{n}=1$ for $\mathrm{Fe}(\mathrm{III}) ; \mathrm{X}=\mathrm{O}$ and $\mathrm{S}$

(b)

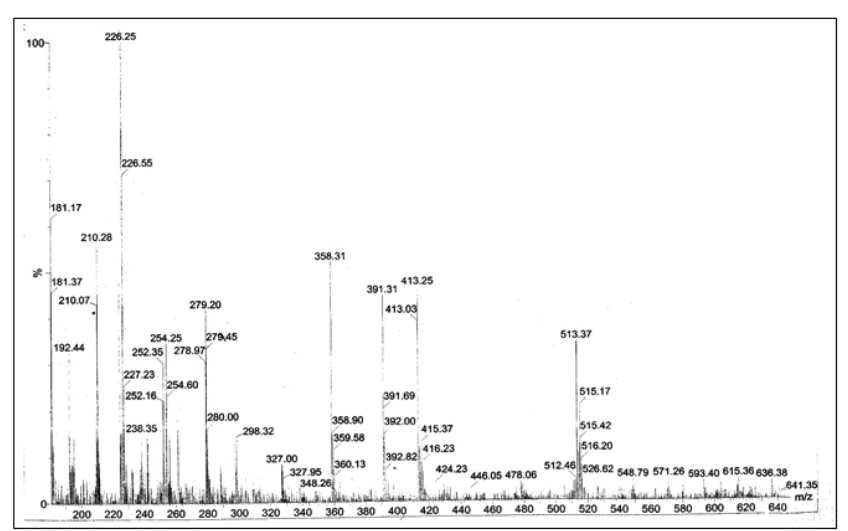

Fig. 1: Proposed structural formula for the complexes (a) $\left[\mathrm{M}(\mathrm{LH}) \mathrm{Cl}_{2}\right]$ and (b) $\left[\mathrm{M}(\mathrm{LH})_{2} \mathrm{Cl}_{2}\right]$

Free radical scavenging activity of methanolic solutions using DPPH assay

Antioxidants can deactivate radicals by two major mechanisms, HAT and SET. Proton-coupled electron transfer and HAT reactions may occur in parallel, and the machanism dominating in a given system will be determined by antioxidant structure and properties, solubility and system solvent. Bond dissociation energy (BDE) and ionization potential(IP) are two major factors that determine the mechanism and the efficiency of antioxidants. ${ }^{54}$

HAT-based methods measure the classical ability of an antioxidant to quench free radicals by hydrogen donation $(\mathrm{AH}=$ any $\mathrm{H}$ donor).

$$
\mathrm{X}^{*}+\mathrm{AH} \longrightarrow \mathrm{XH}+\mathrm{A}^{*}
$$

Relative reactivity in HAT methods is determined by the BDE of the $\mathrm{H}$-donating group in the potential antioxidant, dominating for compounds with DDE of $-10 \mathrm{kCal} / \mathrm{mol}$ and DIP of $<-36 \mathrm{kCal} / \mathrm{mol} .{ }^{54} \mathrm{HAT}$ reaction are solvent and $\mathrm{P}^{\mathrm{H}}$ independent and are usually quite rapid, typically completed in seconds to minutes.

1,1-diphenyl-2-picryl hydrazyl (DPPH) Assay:

The DPPH (Fig.4) radical is one of the few stable organic nitrogen radicals, 
which bears a green color. It is commercially available and does not have to be generated before assay like ABTS ${ }^{+}$. This assay is based on the measurement of the reducing ability antioxidants toward DPPH. The ability can be evaluated by electron spin resonance (EPR) or by measuring the decrease of its absorbance. Antioxidant assay are based on measurement of the loss of DPPH color at $517 \mathrm{~nm}$ after reaction with test compound.

The percentage of the DPPH remaining is calculated as

$$
\% \mathrm{DPPH}_{\mathrm{REM}}^{*}=100 \times\left[\mathrm{DPPH}^{*}\right]_{\mathrm{REM}} /\left[\mathrm{DPPH}^{*}\right]_{\mathrm{T}=0}
$$

The percentage of remaining $\mathrm{DPPH}^{*}\left(\mathrm{DPPH}_{\mathrm{REM}}^{*}\right)$ is proportional to the antioxidant concentration, the concentration that causes a decrease in the initial $\mathrm{DPPH}^{*}$ concentration by $50 \%$ is defined as $\mathrm{IC}_{50}$.

Advantages of the DPPH assay: The test is simple and rapid and needs only a UV-vis spectrophotometer to perform, which probably explains its wide spread use in antioxidant screening. DPPH is a stable nitrogen radical that bears no similarity to the highly reactive and transient peroxyl radicals involved in lipid peroxidation. Many antioxidants that react quickly with peroxyl radicals may react slowly or may even be inert to DPPH due to steric inaccessibility. $\mathrm{DPPH}$ also is decolorized by reducing agents as well as $\mathrm{H}$ transfer, which also contributes to inaccurate interpretations of antioxidant capacity.

Various researchers have used scavenging effect of a chemical on DPPH radical as a quick and reliable parameter to assess the in vitro antioxidant activity. The results of free radical scavenging activity of methanolic solutions of compounds at different concentrations are shown in Table 5 and 6 . It is evident from results that free radical scavenging activity of these compounds was concentration dependent. Among the examined compound the complex $\left[\mathrm{Cu}\left(\mathrm{C}_{11} \mathrm{H}_{19} \mathrm{~N}_{3} \mathrm{~S}\right)_{2} \mathrm{Cl}_{2}\right]$ (5) showed a strong interactive ability with DPPH which was concentration dependent and this compound expressed an $\mathrm{IC}_{50}$ value (Table 7) of $111.0 \mu \mathrm{g} / \mathrm{ml}$ lower than that of ascorbic acid $(136.0 \mu \mathrm{g} /$ $\mathrm{ml})$ and catachin $(203.0 \mu \mathrm{g} / \mathrm{ml})$ which were used as standard. Maximum free radical scavenging activity ( $96.09 \%$ ) was found in compound (5) followed by $(91.10 \%)$ in TBHTSC while least activity $(8.60 \%)$ was observed from TBHSC. The comparative antioxidant activity of compounds against ascorbic acid and catachin as a standard is shown by graphs (Fig. 5).

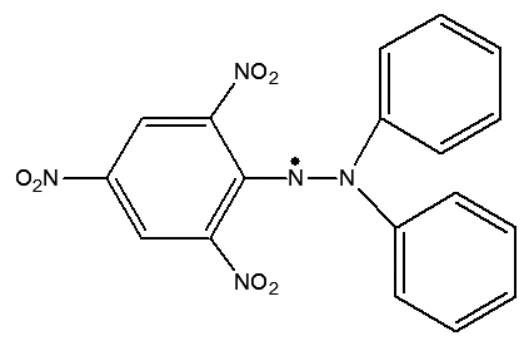

Fig. 4. Structure of 1,1-diphenyl-2-picrylhydrazyl ( $\mathrm{DPPH}^{*}$ ).

Table 5. Absorbance of compounds at different concentration at $517.0 \mathrm{~nm}$

\begin{tabular}{|c|c|c|c|c|c|c|c|c|}
\hline \multirow{2}{*}{ Compound } & \multicolumn{8}{|c|}{ Concentration $(\mu \mathrm{g} / \mathrm{ml})$} \\
\hline & $\mathbf{0}$ & 50 & 100 & 150 & 200 & 250 & 500 & 1000 \\
\hline Ascorbic acid (AA) & 1.023 & 0.809 & 0.600 & 0.475 & 0.325 & 0.255 & 0.105 & 0.051 \\
\hline Catachin (CAT) & 1.023 & 0.887 & 0.689 & 0.524 & 0.350 & 0.230 & 0.081 & 0.045 \\
\hline TBHTSC & 1.023 & 0.847 & 0.682 & 0.522 & 0.429 & 0.317 & 0.121 & 0.091 \\
\hline TBHSC & 1.023 & 0.992 & 0.974 & 0.968 & 0.958 & 0.945 & 0.939 & 0.935 \\
\hline$\left[\mathrm{Fe}(\mathrm{TBHTSC})_{2} \mathrm{Cl}_{2}\right] \mathrm{Cl}$ (3) & 1.023 & 0.840 & 0.659 & 0.530 & 0.488 & 0.441 & 0.345 & 0.268 \\
\hline$\left[\mathrm{Co}(\mathrm{TBHTSC})_{2} \mathrm{Cl}_{2}\right](4)$ & 1.023 & 0.934 & 0.831 & 0.760 & 0.9957 & 0.708 & 0.671 & 0.630 \\
\hline$\left[\mathrm{Cu}(\mathrm{TBHTSC})_{2} \mathrm{Cl}_{2}\right] \mathbf{( 5 )}$ & 1.023 & 0.752 & 0.547 & 0.384 & 0.281 & 0.200 & 0.075 & 0.040 \\
\hline$\left[\mathrm{Fe}(\mathrm{TBHSC})_{2} \mathrm{Cl}_{2}\right] \mathrm{Cl}(\mathbf{6})$ & 1.023 & 0.831 & 0.661 & 0.560 & 0.500 & 0.465 & 0.395 & 0.348 \\
\hline$\left[\mathrm{Co}(\mathrm{TBHSC})_{2} \mathrm{Cl}_{2}\right](7)$ & 1.023 & 0.989 & 0.970 & 0.954 & 0.935 & 0.938 & 0.930 & 0.924 \\
\hline$\left[\mathrm{Cu}(\mathrm{TBHSC})_{2} \mathrm{Cl}_{2}\right](\mathbf{8})$ & 1.023 & 0.985 & 0.934 & 0.908 & 0.905 & 0.887 & 0.866 & 0.836 \\
\hline
\end{tabular}

Table 6. Antioxidant activity of ligands and metal complexes at different concentrations using DPPH assay.

\begin{tabular}{|c|c|c|c|c|c|c|c|c|}
\hline \multirow{2}{*}{ Compound } & \multicolumn{7}{|c|}{ Concentration $(\boldsymbol{\mu g} / \mathbf{m l})$} \\
\cline { 2 - 9 } & $\mathbf{0}$ & $\mathbf{5 0}$ & $\mathbf{1 0 0}$ & $\mathbf{1 5 0}$ & $\mathbf{2 0 0}$ & $\mathbf{2 5 0}$ & $\mathbf{5 0 0}$ & $\mathbf{1 0 0 0}$ \\
\hline $\mathrm{AA}$ & 0 & 20.92 & 41.35 & 53.57 & 68.23 & 75.07 & 89.74 & 95.01 \\
\hline $\mathrm{CAT}$ & 0 & 13.29 & 32.65 & 48.78 & 65.79 & 77.52 & 92.08 & 95.60 \\
\hline TBHTSC & 0 & 17.20 & 33.33 & 48.97 & 58.06 & 69.01 & 88.17 & 91.10 \\
\hline TBHSC & 0 & 03.03 & 04.79 & 05.38 & 06.35 & 07.62 & 08.21 & 08.60 \\
\hline$\left[\mathrm{Fe}(\mathrm{TBHTSC})_{2} \mathrm{Cl}_{2}\right] \mathrm{Cl}(\mathbf{3})$ & 0 & 17.89 & 35.58 & 48.19 & 52.30 & 56.89 & 66.28 & 73.80 \\
\hline$\left[\mathrm{Co}(\mathrm{TBHTSC})_{2} \mathrm{Cl}_{2}\right] \mathbf{( 4 )}$ & 0 & 8.70 & 18.77 & 25.71 & 26.67 & 30.79 & 34.41 & 38.42 \\
\hline$\left[\mathrm{Cu}(\mathrm{TBHTSC})_{2} \mathrm{Cl}_{2}\right] \mathbf{( 5 )}$ & 0 & 26.49 & 46.53 & 62.46 & 72.53 & 80.45 & 92.67 & 96.09 \\
\hline$\left[\mathrm{Fe}(\mathrm{TBHSC})_{2} \mathrm{Cl}_{2}\right] \mathrm{Cl} \mathbf{( 6 )}$ & 0 & 18.77 & 35.39 & 45.26 & 51.12 & 54.54 & 61.39 & 65.98 \\
\hline$\left[\mathrm{Co}(\mathrm{TBHSC})_{2} \mathrm{Cl}_{2}\right] \mathbf{( 7 )}$ & 0 & 03.32 & 05.18 & 06.74 & 08.60 & 08.31 & 09.09 & 09.68 \\
\hline$\left[\mathrm{Cu}(\mathrm{TBHSC})_{2} \mathrm{Cl}_{2}\right] \mathbf{( 8 )}$ & 0 & 03.71 & 08.70 & 11.24 & 11.53 & 13.29 & 15.35 & 18.28 \\
\hline
\end{tabular}


Table 7. $\mathrm{IC}_{50}$ values of test compounds $(\mu \mathrm{g} / \mathrm{ml})$.

\begin{tabular}{|c|c|c|c|c|c|c|c|c|c|c|}
\hline Compound & AA & CAT & TBHTSC & TBHSC & $\mathbf{( 3 )}$ & $\mathbf{( 4 )}$ & $\mathbf{( 5 )}$ & $\mathbf{( 6 )}$ & $\mathbf{( 7 )}$ & $\mathbf{( 8 )}$ \\
\hline $\mathbf{I C}_{\mathbf{5 0}}(\boldsymbol{\mu} \mathbf{g} / \mathbf{m l})$ & 136.0 & 203.0 & 157.0 & $>1000$ & 172.0 & $>1000$ & 111.0 & 190.0 & $>1000$ & $>1000$ \\
\hline
\end{tabular}

Antioxidant actiivty of somesynthetic antioxidants (DPPH ass ay)

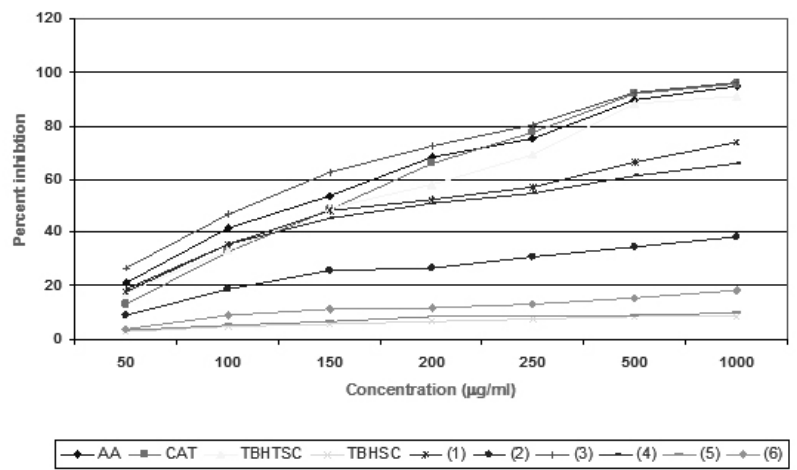

Fig. 5 : Graphical representation of \% antioxidant of ligands and metal complexes (3-8) with respect to standards (Ascorbic acid and Catachin).

\section{CONCLUSION}

The metal complexes isolated during the present study demonstrated that the interaction of metal chloride with semicarbazone/thiosemicarbazone of camphor leads to complexes with 1:2 stoichiometry and are found to be mononuclear. The bidentate nature of both type of ligands have been suggested on the basis of spectral evidences. Results of the antioxidant activity experiments carried out in the laboratory clearly indicate that among the test compound ligand TBHTSC and complexes (3), (5) and (6) showed potent antioxidant activity. All the compounds under study are synthetic in nature and thus these compounds can be referred as synthetic antioxidants.

\section{ACKNOWLEDGEMENTS}

The authors are thankful to Defence Institute of Bio-Energy Research, Pithoragarh (Uttarakhand), for carrying out antioxidant activity and also grateful to Zydus Research Center, Ahmedabad for recording FAB Mass, TGA, elemental analysis and electronic spectra. One of the authors (RS) is grateful to CSIR, New Delhi for providing Senior Research Fellowship to her.

\section{REFERENCES}

1. N.K. Singh, S. Agrawal, R.C. Aggarwal, Synth. React. Inorg. Met.-Org. Chem. 15, 75 (1985).

2. S.B. Padhye, G.B. Kauffman, Coord. Chem. Rev. 63, 127 (1985).

3. D.X. West, S.B. Padhye, P.B. Sonawane, R.C. Chikte, Structure and Bonding, 76, 1 (1991).

4. D.X. West, S.B. Padhye, P.B. Sonawane, R.C. Chikte, Asian J. Chem. Rev. 4(1), 125 (1990).

5. I. Ana Matesanz, P. Souza, Mini Rev. Med. Chem. 9(12), 1389 (2009).

6. H. Beraldo, D. Gambino, Mini Rev. Med. Chem. 4, 31 (2004).

7. D. Singh, R.V. Singh, J. Inorg. Biochem. 50, 227 (1993).

8. N.C. Kasuga, K. Sekino, C. Koumo, N. Shimada, M. Ishikawa, K. Nomiya, J. Inorg. Biochem. 84, 55 (2001).

9. D.J. Bauer, Thiosemicarbazones in chemotherapy of virus disease, Pergaman Press, Oxford, 1972.

10. D.X. West, A.A. Nassar, F.A. El-saied, M.I. Ayad, Transition Met. Chem. 23, 423 (1998).

11. M.B. Halli, Z.S. Qureshi, Indian J. Chem. 43A, 2347 (2004).

12. K.H. Reddy, M.S. Babu, P.S. Babu, S. Dayananda, Indian J. Chem. 43A, 1233 (2004)

13. A.D. Naik, V.K. Revankar, Indian J. Chem. 43A, 1447 (2004).

14. M.A. Ali, S.E. Livingstone, Coord. Chem. Rev. 13, 101 (1974).

15. M.J.M. Campbell, Coord. Chem. Rev. 15, 279 (1975).

16. S. Padhyé, G.B. Kauffman, Coord. Chem. Rev. 63, 127 (1985).
17. M.N. Hughes, The Inorganic Chemistry of Biological Processes, Wiley, London, 1972.

18. R.W. Byrnes, M. Mohan, W.E. Antholine, R.X. Xu, D.H. Petering, Biochemistry, 29, 7046 (1990).

19. D.X. West, A.E. Liberta, S.B. Padhye, R.C. Chikate, P.B. Sonawane, A.S. Kumbhar, R.G. Yerande, Coord. Chem. Rev. 123, 49 (1993).

20. M.B. Ferrari, G.G. Fava, E. Leporati, G. Pelosi, R. Rossi, P. Tarasconi, R. Albertini, A. Bonati, P. Lunghi, S. Pinelli, J. Inorg. Biochem. 70, 145 (1998).

21. M.C. Rodríguez-Argüelles, A. Sánchez, M.B. Ferrari, G.G. Fava, C. Pelizzi, G. Pelosi, R. Albertini, P. Lunghi, S. Pinelli, J. Inorg. Biochem. 73, 7 (1999).

22. D.K. Demertzi, P.N. Yadav, M.A. Demertzis, M. Coluccia, J. Inorg. Biochem. 78, 347 (2000).

23. M.B. Ferrari, S. Capacchi, G. Reffo, G. Pelosi, P. Tarasconi, R. Albertini, S. Pinelli, P. Lunghi, J. Inorg. Biochem. 81, 89 (2000).

24. R. Sharma, A.K. Bansal, M. Nagar, Indian J. Chem. 44A, 2255 (2005); R. Sharma, S.K. Agarwal, S. Rawat, M. Nagar, Transition Met. Chem. 31, 201 (2006).

25. R. Sharma, M. Nagar, Phosphorus, Sulfur and Silicon, 181, 2863 (2006); R. Sharma, M. Nagar, M. Agarwal, H. Sharma, J. Enzym. Inhib. Med. Chem. 24(1), 197 (2009).

26. D. Kalemba, A. Kunicka, Curr. Med. Chem. 10, 813 (2003).

27. W.F. Beyer, I. Fridovich, Manganese in metabolism and enzyme function, Academic press, New York, 1986; pp. 193.

28. I.A. Patel, P. Patel, S. Goldsmith, B.T. Thaker, Indian J. Chem. 38A, 427 (1999).

29. M. Tümer, H. Köksal, M.K. Sener, S. Serin, Transition Met. Chem. 24, 414 (1999).

30. G. Albertin, E. Bordignon, A.A. Orio, Inorg. Chem. 14, 1411 (1975).

31. D.K. Demertzi, A. Domopoulow, M.A. Demertzis, J. Valdés-Martínez, S. Hernández-Ortega, G. Espinosa-Pérez, D.X. West, M.M. Salberg, G.A. Bain, P.D. Bloom, Polyhedron, 15, 2587 (1996).

32. D.X. West, C.S. Carlson, A.E. Liberta, J.N. Albert, C.R. Daniel, Transition Met. Chem. 15, 341 (1990).

33. D.X. Tan, L.C. Manchester, R. Sainz, J.C. Mayo, F.L. Alvares, R.J. Reiter, Expert. Opin. Ther. Pat. 13, 1513 (2003).

34. T. Finkel, N.J. Holbrook, Nature (London), 408, 239 (2000).

35. W. Droge, Physiol. Rev. 82, 47 (2002).

36. N. Noguchi, Free Rad. Biol. Med. 33, 1480 (2002).

37. C.A. Rice-Evans, N.J. Miller, G. Paganga, Free Rad. Biol. Med. 20(7), 933 (1996).

38. B. Halliwell, J.M. Gutteridge, Biochem. J. 219, 1 (1984).

39. S.R. Maxwell, Drugs, 49, 345 (1995).

40. E. Niki, H. Shimaski, M. Mino, Antioxidantism-free and biological defense, Gakkai Syuppn Center, Tokyo, 1994; pp. 3-16.

41. R.L. Prior, G. Cao, J. Am. Nutraceut. Assoc. 2, 46 (1999).

42. B.N. Brousse, A.G. Moglioni, M.M. Alho, Á. Álvarez-Larena, G.Y. Moltrasio, N.B. D’Accorso, ARKIVOC, X, 14 (2002).

43. A.I. Vogel, Text Book of Practical Quantitative Chemical Analysis, 5th Edn; ELBS, London, 1989.

44. T. Hatano, R. Edamatsu, M. Hiramatsu, A. Mori, Y. Fujita, T. Yasuhara, T. Yoshida, T. Okuda, Chem. Pharm. Bull. 37, 2016 (1989).

45. G. Cao, E. Sofic, R.L. Prior, Free Rad. Biol. Med. 22, 749 (1997).

46. V. Panteleon, I.K. Kostakis, P. Marakos, N. Pouli, I. Andreadou, Bioorg. Med. Chem. Lett. 18, 5781 (2008).

47. Y. Harek, L. Larabi, L. Boukli, F. Kadri, N. Benali-Cherif, M.M. Mostafa, Transition Met. Chem. 30, 121 (2005).

48. A.B.P. Lever, "Inorganic Electronic Spectroscopy", 2nd Ed.; Elsevier, 1984.

49. J. Lewis, R.G. Wilkins, Modern Coordination Chemistry, Interscience, New York, 1967.

50. L. Casella, M. Gullotti, J. Am. Chem. Soc. 103, 6338 (1981).

51. K.C. Patel, D.E. Goldberg, J. Inorg. Nucl. Chem. 34, 637 (1972).

52. Y. Nishida, S. Kida, Coord. Chem. Rev. 27, 275 (1979).

53. I.M. Proctor, B.J. Hathaway, P. Nicholls, J. Chem. Soc. A. 1678 (1968).

54. J.S. Wright, E.R. Johnson, G.A. Dilabio, S. Am. Chem 123, 1173 (2001). 